\title{
VALORIZAÇÃO DA CULTURA AFRO-BRASILEIRA EM SALA DE AULA
}

\section{Maria Benedita Alves Muniz ${ }^{1}$ \\ Ana Maria da Costa ${ }^{2}$ \\ Ana Enedi Prince ${ }^{3}$}

Resumo: Considerando que ainda na atualidade existe um grande preconceito em relação a etnia negra em nosso país, ocorreu a necessidade da promulgação da Lei 10.639/2003, que determina a obrigatoriedade do ensino relativo a essa etnia no contexto escolar. Reconhecendo que essa etnia foi primordial na constituição da população brasileira, faz-se necessário à sua valorização. Sendo assim, o grande legado cultural deixado por eles, bem como as riquezas do continente africano devem ser ressaltados em sala de aula. Somente por intermédio dessa valorização, iremos acabar com o preconceito racial existente em nosso país.

Palavras-chave: Escravidão; Respeito; Legado cultural; Preconceito; Discriminação.

\footnotetext{
${ }^{1}$ História/Universidade do Vale do Paraíba/Platanus, Brasil. E-mail: benealvesIl@hotmail.com.

2 História/Universidade do Vale do Paraíba/Platanus, Brasil. E-mail: anamari66@outlook.com.

${ }^{3}$ História/Universidade do Vale do Paraíba/Platanus, Brasil. E-mail: prince@univap.br.
} 